\title{
Zea Mays Plant as a Suitable Phytoremediator for Soil Matrix Contaminated with Cadmium
}

\author{
${ }^{*}$ A. N. Amitaye and J. I. Uche \\ Department of Chemistry, College of Education, P. M. B 2090, Agbor, Delta State \\ [*Corresponding Author iupac.azuka@yahoo.co.uk]
}

\section{ABSTRACT}

As a green technique for environmental protection and sustainability, Zea mays capacity to bioaccumulate cadmium was studied. The impacts of cadmium on some plant growth parameters such as vine length, leaf area, fresh shoot weight and fresh root weight were monitored for the Zea mays over a period of 28days. It was observed that the level of cadmium (Cd) sorbed by the Zea mays seedling increased with increase in cadmium $(\mathrm{Cd}$ ) load in the soil material. The uptake efficiency which ranged from $24.8-54.6 \%$ decreases with increase in the cadmium level in the soil. The plant was more sensitive to cadmium stress at the early stage of development (7day old seedlings) than at later stage (21day old seedlings) though, germination rate was not significantly affected by cadmium stress. Biomass production as well as the leaf area was not significantly affected by the cadmium stress on the maize seedlings. It was also observed that amount of cadmium translocated to the shoot was three times the amount accumulated at the root hence, little or no potential effect on the crop yield and quality. Zea mays may be used as phytoremediator for soil contaminated with cadmium.

Key Words: Zea mays, growth parameters, phytotoxicity, uptake efficiency and cadmium

\section{INTRODUCTION}

Contamination of the ecosystem with heavy metals is a serious concern in both developed and developing nations of the world (Amitaye, 2011; Okuo et al., 2007; Ogboi, 2005). What are more significant for toxic metals contamination are their cumulative and nonbiodegradability properties in the environment. However, it has been observed that increase in anthropogenic activities is the bane for the prevalent dramatic increase in metal and other toxic contaminants in the environment which had been necessitated majorly by technological advancement and population explosion (Uche \& Amitaye, 2013).

Mineralization of crops or application of agricultural inputs such as pesticides and fertilizers or treatment of soil with sewage sludge has been identified as common pathways of soil contamination (Shuaibu, 2013). Other identified contaminant sources of heavy metals in soil include among others: automobile emissions, use of lead paints and pipes, batteries, PVC plastics, cigarettes, mining and smelting activities (Jacob et al., 2013; Wong, 1996). Beside the retrogressive effects on agricultural crop productions and quality, contamination of agricultural lands with heavy metals can have grave health consequence on the biotic community, as humans in particular, can become poisoned through the food chain. As reported by Jacob et al. (2013), toxic metal ingestion by human can directly or indirectly damage the DNA, hence, increasing the risk of cancer. Moreover, birth defects as well as impaired organ functioning had been reported in animals and human beings that consumed metal contaminated food materials (Ademoroti, 1996; Sharma, 2006). Thus, there is urgent need for environmental clean- up of heavy metals since almost all heavy metals are non-biodegradable and as such persistently active in the ecosystem to cause deleterious effects on the biotic entities. As a green technique for environmental protection and sustainability, phytoremediation is generally an eco-friendly and cost-effective approach of decontaminating the environment of toxic contaminants, especially toxic metal 
contaminants such as Arsenic, chromium, lead, cadmium and mercury. As simply defined by Cunningham, et al. (1996); McCutcheon and Schnoor (2003), phytoremediation is the in situ use of plants and their associated microorganisms to degrade, contain or render harmless contaminants in soil or groundwater or any other contaminated media. This soil remediation technique (phytoremediation) has been used to decontaminate sites contaminated with a variety of contaminants including heavy metals, solvents, PAHs, PCBs, hydrocarbons, radionuclides, explosives, and pesticides.

According to Kumar et al. (1995) and Belimov et al. (2005) Plants suitable for phytoremediation should have a high biomass production with enhanced metal tolerance and metal uptake potential. Although hyper-accumulator plants have exceptionally high metal accumulating capacity, most of these have a slow growth rate and often produce limited amounts of biomass. Specifically, researchers have observed that some plant species are endemic to metalliferous soil and can tolerate greater than usual amount of heavy metals or other toxic compounds (Burton \& Peterson, 1979). For instance, Miller et al. (1995) reported that Alfalfa had the ability of accumulating Cadmium in soil receiving high rates of sewage sludge (equivalent to $4.6 \mathrm{Kg}$ $\mathrm{Cd} / \mathrm{hm}^{2}$ ). Similarly, sunflower has been used to reduce Uranium concentration in water, up to 95\% (Al-Salama, 2002). Moreover, Aberben has been used to remove trichloroethylene and polycyclic aromatic hydrocarbons (PAHs) from ground water (Zhi-xin et al., 2007). Studies have also confirmed that certain plant species can take up chlorinated solvents from the groundwater in the root zone (Chappel, 1997; Schnoor, 1997). Once plant takes up the solvent, it can store the chemical in its body via covalent bonding with plant lignin (Schnoor, 1997). The plant may metabolise the chemical to other compounds. Since plants have varying potential to absorb metals from soil through their roots and distribute them (the metals) via their tissues (xylem and phloem) to other parts of the plant, it is therefore paramount to identify plant species with very good capacity to accumulate high metal contaminants concentrations with little or no effect on plant's growth and development as well as productivity. Hence, the focus of this study is to evaluate the uptake potential and efficiency of cadmium by Maize (Zea mays) and the effect on some crop growth parameters.

\section{MATERIALS AND METHODS Reagents and apparatus}

The materials used in this experiment include: $\mathrm{HNO}_{3}, \mathrm{H}_{2} \mathrm{SO}_{4}$ (for rinsing), $\mathrm{HClO}_{4}$ (perchloric acid), distilled water, ruler $(\mathrm{cm})$, cadmium chloride $\left(\mathrm{CdCl}_{2}\right)$, ammonium pyrrolidine dithiocarbamate solution, methyl-isobutylketone solution (for $\mathrm{Cd}$ extraction), beakers, conical flask, filter paper (Whiteman No.4), porcelain mortar and pestle, electric oven, weighing balance (mettle Toledo), Digital Planimeter (Kp$90 \mathrm{~N}$ ), setra bl-40s precision electronic balance, measuring cylinder, heating mantle, Atomic Absorption Spectrophotometer (Bulk Model 210 VG) with air-acetylene flame.

\section{Preparation of soil sample}

Humus soil was collected from botanical garden in University of Benin, Benin city, Edo state, Nigeria. The soil was collected at a depth of 0 $30 \mathrm{~cm}$ at five (5) different locations in the garden. A composite sample was made by mixing the soil together and then transported in polythene bag to the laboratory. The soil sample was air dried and sieved to remove debris and stones before it was screened for cadmium content using Atomic Absorption Spectrophotometer (AAS) (Bulk Model 210 VG). Soil preparation, was carried-out as reported by Shuaibu (2013). One kilogramme $(\mathrm{kg})$ each of the soil samples were weighed into five polythene bags labeled $X, A, B, C$ and $D$. Sample $X$ serves as the control. Samples A, B, C and $D$ are the experimental/test groups. The bags were perforated to allow for good aeration. The soil samples were gradually treated with different amount of Cadmium metal as Cadmium chloride $\left(\mathrm{CdCl}_{2}\right)$. The different amounts of Cadmium used for the study were $0,5,10,15$ and $30 \mu \mathrm{g} / \mathrm{g}$ for soil samples $X, A, B, C$, and $D$ respectively. This 


\section{Nigerian Journal of Basic and Applied Science (June, 2017), 25(1): 111-119}

study was however, conducted in three-fold i.e. each experimental/test groups and the control were prepared in triplicate.

\section{Planting and seed germination}

Four Maize (Zea mays) seeds were sown in both control and the Cadmium treated soil samples (the test groups) and were watered morning and evening to keep the soil moist. The polythene bags were thereafter left in the field for germination for a period of four weeks (28days). The percentage seed germination was taken on the $7^{\text {th }}$ day and seeds which failed to sprout on the 7 th day were regarded as not having germinated or ungerminated. The total number of Zea mays seeds sowed was 60 [four (4) seeds sowed in three (3) experimental set-up for each experimental/test groups: A, B, C, \& D and three (3) experimental set-up for the control: X)].

\section{Early seedling growth and sample collection}

Early seedling growth rate was estimated using a ruler $(\mathrm{cm})$ to measure the vine length from the soil level to the terminal bud of 7 day old plant. Values were reported as mean \pm standard deviation

The root and shoot of the seedlings were separately collected or harvested on the 7,14 , 21 , and 28 day old maize seedlings from each of the experimental/test groups. At each instance, the root and shoot were washed with distilled water to remove dust and adhering soil particles. The samples were air-dried before taking the respective weight of the fresh root and shoot for the 7 and 21 day old seedligs. Root and shoot fresh weights were determined using the Setra BL-40S precision electronic balance. The airdried roots and shoots collected from the experimental/test groups on the $7^{\text {th }}, 14^{\text {th }}, 21^{\text {st }}$ and $28^{\text {th }}$ day intervals were pooled together as a sample and the pooled samples from each of the experimental/test groups were then oven dried at a temperature of $95^{\circ} \mathrm{C}$ for about 24hours until each sample brittle and crisp. The dried samples were separately grounded into fine particles using clean acid-washed porcelain mortar and pestle and then sieved with a $250 \mu \mathrm{m}$ particle size mesh.

\section{Digestion of plant sample}

One (1.0) $\mathrm{kg}$ of each of the plant powder samples were separately digested in $20 \mathrm{~cm}^{3} \mathrm{HNO}_{3}: \mathrm{HClO}_{4}$ acid mixture $(5: 1 \mathrm{v} / \mathrm{v})$ on a hot plate till a clear solution was obtained. After the disappearance of brown fume, the experimental set up was allowed to cool and then transferred into $100 \mathrm{ml}$ volumetric flask and made to volume with distilled water. The digested samples were filtered using filter paper (Whatman No. 4) and prepared for extraction. Exactly $20 \mathrm{ml}$ of digested samples were collected and separately extracted. This was done by adding $1 \mathrm{ml}$ ammonium pyrrolidine dithiocarbamate and $5 \mathrm{ml}$ methyl-isobutylketone and then centrifuged for 10 minutes. Thereafter, the organic layer was collected into a clean beaker. The remaining liquid was extracted using $5 \mathrm{ml}$ of methyl-isobutylketone. The two extracts obtained were mixed troughly and the amount of cadmium (Cd) was determined using Atomic Absorption Spectrophotometer at a wavelength of 228.8nm (Buck Scientific Model 200A/210) with double beam and background corrector. Twenty (20)ml distilled water was digested and extracted as blank by the same procedure as described above. The concentration of Cadmium, $\mathrm{Cd}$, was recorded in $\mu \mathrm{g} / \mathrm{g}$.

\section{Statistical analysis}

The data collected were subjected to one-way analysis of variance (ANOVA) techniques and Ftest, to ascertain if there is any significant difference in the growth parameters examined between the test and the control groups. Where there is significant difference, post-hoc analysis was done using Scheffe test at 5\% level of probability to compare differences. Transport Index (T.I) and the Bioaccumulation Coefficient (B.C) were calculated according to the method described by Gomez and Gomez (1984). 


\author{
Transport Index $(T . I)=\frac{\text { Shoot cadmium content } x 100}{\text { Total plant cadmium content }}$ \\ Bioaccumulation Coefficient $(B C)=\underline{\text { Cadmium content }(\mu \mathrm{g} / \mathrm{g}) \text { in dry plant tissue }}$ \\ Cadmium content $(\mu \mathrm{g} / \mathrm{g})$ in soil
}

Also, the uptake efficiency was determined by the expression below:

Uptake Efficiency (U.E.) = Bioaccumulation Coefficient (B.C.) $\times 100$

\section{RESULTS AND DISCUSSION RESULTS:}

The germination percentage ranged from 75 $91.7 \%$ (Table 1). The nonattainment of $100 \%$ germination for the experimental/test groups could not be due to cadmium contamination because only $91.7 \%$ was recorded for the control treatments. The seed germination rate ranged from 1.29-1.57 plants per day. This is a good germination rate and it is an indication of very little or no toxicity effect on Zea mays' potency to grow or germinate on cadmium polluted medium (environment). Nevertheless, no significant difference was observed in percentage germination between experimental/test and the control treatments. Moreso, the maximum value for vine length, fresh root weight; fresh shoot weight and leaf area was observed in control (cadmium-free soil) and minimum values were reported in sample treated with $30 \mathrm{ug} / \mathrm{g}$ of cadmium (Table1).

When the maize seedling was exposed to $5 \mu \mathrm{g} / \mathrm{g}$ initial cadmium $(\mathrm{Cd})$ concentration, the amount of cadmium (Cd) sorbed by the plant was $2.73 \mu \mathrm{g} / \mathrm{g}$ which correspond to $54.6 \%$ uptake efficiency. When exposed to $10 \mu \mathrm{g} / \mathrm{g}$ initial cadmium (Cd) concentration, the maize seedling sorbed 5.24 $\mu \mathrm{g} / \mathrm{g}$ of cadmium, which corresponds to $52.4 \%$ uptake efficiency. When the maize seedlings that were separately exposed to 15 and $30 \mu \mathrm{g} / \mathrm{g}$ of initial cadmium (Cd) concentrations, the respective amounts of cadmium $(\mathrm{Cd})$ sorbed by the plant as well as the uptake efficiencies were $6.154 \mu \mathrm{g} / \mathrm{g}(41.0 \%)$ and $7.445 \mu \mathrm{g} / \mathrm{g}(24.8 \%)$ (Table 4).

Moreso, the levels of cadmium metal accumulated at the plant's root ranged from
$1.933-5.265 \mu \mathrm{g} / \mathrm{g}$ which is almost three times the level of cadmium translocated to the plant's shoot $(0.797-2.180 \mu \mathrm{g} / \mathrm{g})$ while the leaf area values ranged from $19.7 \pm 13.1-39.9 \pm 10.3 \mathrm{~cm}^{2}$ and $45.6 \pm 7.0-64.8 \pm 18.0 \mathrm{~cm}^{2}$ for 7 day and 21 day plants respectively. The results show that the leaf areas were slightly affected by cadmium concentrations in the soil.

\section{DISCUSSION}

The reduction in percentage germination with increased cadmium concentration could be attributed to lower infusibility of water and nutrients which could have resulted from increased chemical interactions at the root or absorption site. Water, heat and nutrient uptake are basic essential requirement for plant germination and growth. Similar observation has been reported by Bahrami, et al., (2012). This also explains why there was a linear trend in the decline in the growth parameters examined with increase in cadmium concentration in the sample matrix (Fig. 1 \& 2). It has also been observed that the level of cadmium ( $\mathrm{Cd}$ ) sorbed by the maize seedling increased with increase in cadmium (Cd) load in the soil material (Table1). This implies that cadmium $(\mathrm{Cd})$ uptake by Zea mays seedling is concentration dependent. As the levels of cadmium $(\mathrm{Cd})$ exposed to the maize seedling increased, the amount of metal uptake by the plant also increased. However, the efficiency of the maize seedling to sorbed cadmium (Cd) decreased with increase in cadmium metal load in the soil. This result is similar to that reported by Shuaibu (2013) who studied lead uptake by Zea Mays seedlings. 
Table 1: Effect of cadmium (Cd) concentration on germination and growth of Zea mays

\begin{tabular}{|c|c|c|c|c|c|c|c|c|c|c|}
\hline \multirow{2}{*}{$\begin{array}{c}{[\mathrm{Cd}]} \\
\text { in soil } \\
(\mu \mathrm{g} / \mathrm{g})\end{array}$} & \multirow{2}{*}{$\begin{array}{c}\text { Seed } \\
\text { Germ. } \\
\text { Pct. } \\
\{(Z / 12) \times 1 \\
00\}\end{array}$} & \multirow{2}{*}{$\begin{array}{l}\text { Seed } \\
\text { Germ. } \\
\text { Rate } \\
\text { (Plant/ } \\
\text { day) }\end{array}$} & \multirow{2}{*}{$\begin{array}{c}\text { Early } \\
\text { seedling } \\
\text { growth rate } \\
\text { (Vine length } \\
\text { of 7-day old } \\
\text { seedlings) }\end{array}$} & \multirow{2}{*}{$\begin{array}{c}\text { Vine } \\
\text { length of } \\
21-\text { day } \\
\text { old } \\
\text { seedlings }\end{array}$} & \multicolumn{2}{|c|}{ Leaf area $\left(\mathrm{cm}^{2}\right)$} & \multicolumn{2}{|c|}{$\begin{array}{l}\text { Fresh shoot weight } \\
\qquad(100 \mathrm{~g})\end{array}$} & \multicolumn{2}{|c|}{ Fresh root weight $(100 \mathrm{~g})$} \\
\hline & & & & & $\begin{array}{c}\text { for 7-day } \\
\text { old } \\
\text { seedling }\end{array}$ & $\begin{array}{l}\text { for 21-day } \\
\text { old } \\
\text { seedling }\end{array}$ & $\begin{array}{l}\text { for 7-day } \\
\text { old } \\
\text { seedling }\end{array}$ & $\begin{array}{c}\text { for 21-day } \\
\text { old } \\
\text { seedling }\end{array}$ & $\begin{array}{l}\text { for } 7 \text {-day old } \\
\text { seedling }\end{array}$ & $\begin{array}{l}\text { for 21-day olc } \\
\text { seedling }\end{array}$ \\
\hline 0 & $91.7^{a}$ & 1.57 & $11.2 \pm 0.2^{\mathrm{a}}$ & $16.3 \pm 1.5^{a}$ & $39.9 \pm 10.3^{a}$ & $64.8 \pm 18.0^{a}$ & $20.9 \pm 0.14^{a}$ & $63.3 \pm 1.8^{a}$ & $31.95 \pm$ & $54.55 \pm 5.02^{a}$ \\
\hline 5 & $91.7^{a}$ & 1.57 & $10.9 \pm 0.6^{a b}$ & $15.7 \pm 1.5^{a}$ & $33.9 \pm 4.5^{\mathrm{a}}$ & $63.5 \pm 0.4^{a}$ & $19.5 \pm 1.56^{b}$ & $46.4 \pm 6 . b^{b}$ & $29.05 \pm 1.34^{b}$ & $20 \pm 1.27 a$ \\
\hline 10 & $83.3^{a}$ & 1.43 & $10.8 \pm 0.6^{\mathrm{ab}}$ & $14.7 \pm 2.1^{a}$ & $31.0 \pm 1.6^{a}$ & $51.1 \pm 6.4^{a}$ & $19.2 \pm 1.13 c$ & $37.5 \pm 8.1^{b}$ & $27.50 \pm 0.40^{c}$ & $3.04 \mathrm{c}$ \\
\hline 15 & $83.3^{a}$ & 1.43 & $9.8 \pm 0.6^{b}$ & $14.3 \pm 0.6^{a}$ & $29.0 \pm 2.6^{a}$ & $47.6 \pm 9.4^{a}$ & $16.7 \pm 0.99 d$ & $36.1 \pm 8.3^{b}$ & $17.95 \pm 1.34 \mathrm{~d}$ & $32.15 \pm 8.41^{c}$ \\
\hline 30 & $75.0^{a}$ & 1.29 & $8.5 \pm 0.9 b$ & $12.4 \pm 0.6^{a}$ & $19.7 \pm 13.1^{a}$ & $45.6 \pm 7.0^{a}$ & $15.1 \pm 1.13^{e}$ & $28.9 \pm 0.1^{c}$ & $16.15 \pm 0.49 \mathrm{e}$ & $28.10 \pm 3.04^{\mathrm{c}}$ \\
\hline
\end{tabular}

Means with similar letters in each column are not significant at $5 \%$ level of probability; Germ. = Germination; pct. = percentage;

$Z=$ Total number of germinated seeds

Table 2: Correlation coefficient among various growth parameters of 7 day old Zea mays seedling.

\begin{tabular}{ccccc}
\hline & $\begin{array}{c}\text { Shoot } \\
\text { length }\end{array}$ & $\begin{array}{c}\text { Fresh } \\
\text { shoot } \\
\text { weight }\end{array}$ & $\begin{array}{c}\text { Fresh } \\
\text { root } \\
\text { weight }\end{array}$ & $\begin{array}{c}\text { Leaf } \\
\text { area }\end{array}$ \\
\hline $\begin{array}{c}\text { Germination } \\
\%\end{array}$ & 0.907 & 0.898 & 0.865 & 0.945 \\
$\begin{array}{c}\text { Shoot length } \\
\text { Fresh shoot }\end{array}$ & 1.000 & 0.974 & 0.940 & 0.947 \\
$\quad$ weight & & 1.000 & 0.986 & 0.955 \\
$\begin{array}{c}\text { Fresh root } \\
\text { weight }\end{array}$ & & & 1.000 & 0.899 \\
Leaf area & & & & \\
\hline Significant at 0.05 probability level & & 1.000 \\
\hline
\end{tabular}

Significant at 0.05 probability level
Table 3: Correlation coefficient among various growth parameters of 21day old Zea mays seedling.

\begin{tabular}{|c|c|c|c|c|}
\hline & $\begin{array}{l}\text { Shoot } \\
\text { length }\end{array}$ & $\begin{array}{c}\text { Fresh } \\
\text { shoot } \\
\text { weight }\end{array}$ & $\begin{array}{c}\text { Fresh } \\
\text { root } \\
\text { weight }\end{array}$ & $\begin{array}{l}\text { Leaf } \\
\text { area }\end{array}$ \\
\hline Germination \% & 0.979 & 0.868 & 0.940 & 0.935 \\
\hline Shoot length & 1.000 & 0.895 & 0.939 & 0.900 \\
\hline $\begin{array}{l}\text { Fresh shoot } \\
\text { weight }\end{array}$ & & 1.000 & 0.946 & 0.905 \\
\hline $\begin{array}{c}\text { Fresh root } \\
\text { weight }\end{array}$ & & & 1.000 & 0.985 \\
\hline Leaf area & & & & 1.000 \\
\hline
\end{tabular}


Table 4: Cadmium uptake by Zea Mays seedling grown on soil supplemented with different [Cd] for a period of 28days

\begin{tabular}{ccccccc}
\hline $\begin{array}{c}\text { [Cd] in } \\
\text { soil } \\
(\mu \mathrm{g} / \mathrm{g})\end{array}$ & $\begin{array}{c}\text { Cadmium uptake } \\
(\mu \mathrm{g} / \mathrm{g} \mathrm{dry} \mathrm{wt)} \\
\text { Root }\end{array}$ & Shoot & $\begin{array}{c}\text { Ratio of [Cd] } \\
\text { accumulated in } \\
\text { Root to that in } \\
\text { the shoot }\end{array}$ & $\begin{array}{c}\text { Transport } \\
\text { Index }(\%)\end{array}$ & $\begin{array}{c}\text { Bioaccumulation } \\
\text { Coefficient of } \\
\text { Cadmium }\end{array}$ & $\begin{array}{c}\text { Uptake } \\
\text { Efficiency }(\%)\end{array}$ \\
\hline 0 & NDL & NDL & - & - & - & - \\
5 & 1.933 & 0.797 & 2.425 & 29.194 & 0.546 & 54.6 \\
10 & 3.833 & 1.408 & 2.722 & 26.865 & 0.524 & 52.4 \\
15 & 4.575 & 1.579 & 2.897 & 25.658 & 0.410 & 41.0 \\
30 & 5.265 & 2.180 & 2.415 & 29.281 & 0.248 & 24.8 \\
\hline
\end{tabular}

$[C d]=C a d m i u m$ concentration $(\mu g / g) ; N D L=N o t$ within Detection

The explanation for the above observation is that at low metal concentration, there is little or low competition between ions at the uptake sites while the opposite occurs at high metal concentrations (Greger, 1997). The Zea mays plant retained more cadmium at the root region than any other parts of the plant. This result is similar to that obtained for Capiscum anum (pepper) as reported by Tukura et al. (2012). Also, this result is in consonance with that of Greger and Landberg (1995) that higher up in the plant, the lower the heavy metal concentration and it followed this distribution pattern: fibrous root >storage root > stem > leaves; the fibrous root retains the highest metal concentration. However, the result of this study does not correspond with the finding of Riffat, et al. (2010) who reported that cadmium level in the aerial parts of vegetable crops was higher than in the roots. This clearly explains why the mean values of the root fresh weight of experimental/test treatments, for 7day old maize seedlings, were significantly different from each other as well as from the control (Table1). It indicates strong sensitivity of the roots to cadmium stress and as such there was significant decrease in the fresh root weight with increase in cadmium stress levels in the soil.

Root sensitivity to cadmium stress became minimal as the plant get older. Infact, there was no significant difference in the mean values of 21 day old Zea mays seedlings stressed with $5 \mu \mathrm{g} / \mathrm{g}$ cadmium level and the control though, there existed slim differences in the mean values of control and the other experimental/test groups. However, no marked difference existed among the experimental/test groups (Table1). This shows that the seedlings exhibited more clear symptoms of phytotoxicity at the tender stage of development (7days of age). Although, similar observation were made for the fresh shoot weight, the symptoms of phytotoxicity were expressed more clearly in the roots than in the shoots and this may be due to the reported higher concentrations of cadmium at the roots region of the plant(Fig.I).

There was significant difference in early seedling growth rate between the experimental/test and the control treatments (Table 1). Nevertheless, there was no marked difference in the mean values of maize seedlings, in terms of early seedling growth rate, cultivated on soil with less than $15 \mu \mathrm{g} / \mathrm{g}$ of cadmium but there was significant difference in early seedling growth rate for maize cultivated on soil contaminated with 15 $\mu \mathrm{g} / \mathrm{g}$ or greater than $15 \mu \mathrm{g} / \mathrm{g}$ of cadmium (Table 1). On a longer time scale, there was no significant difference among the 21day old maize seedlings studied. 


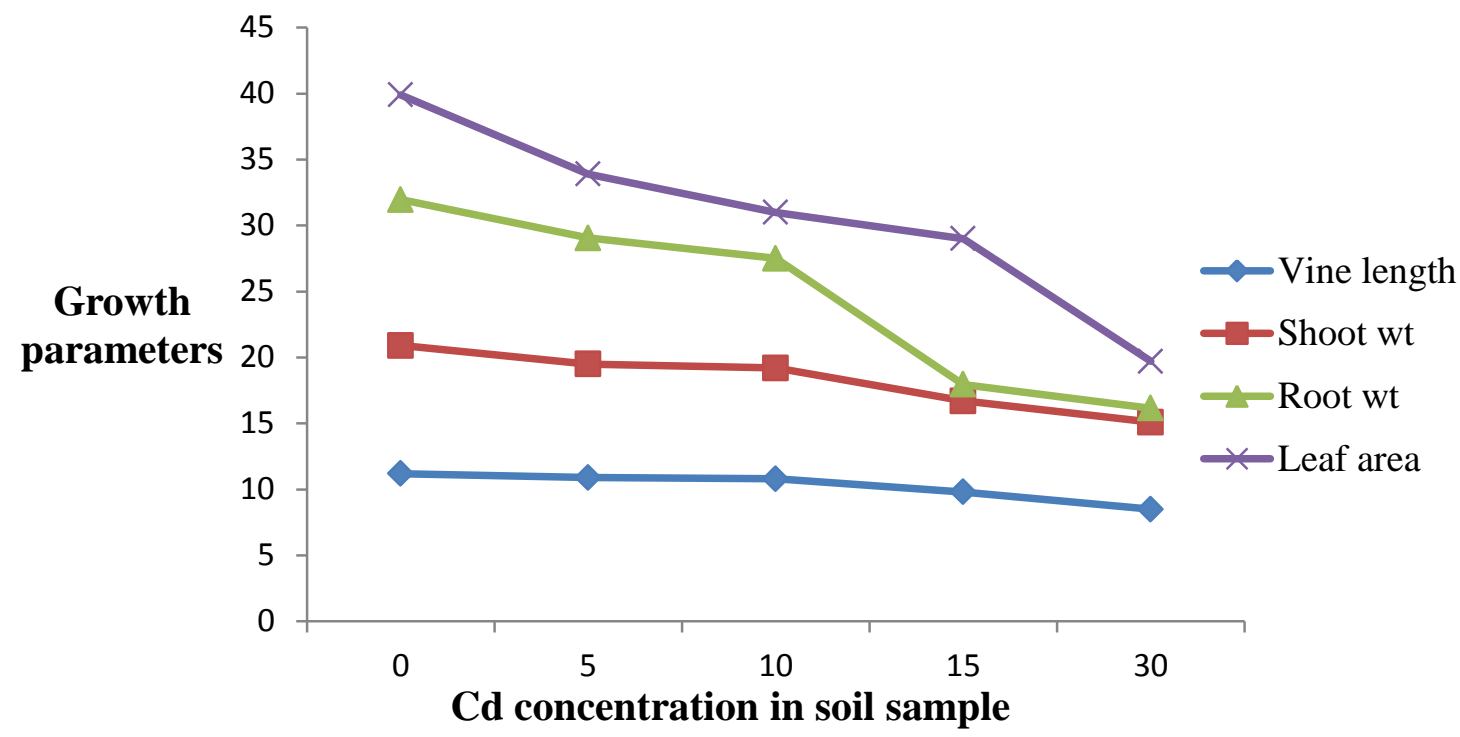

Figure 1: Effect of [Cd] on Growth parameters of 7 day old maize seedling

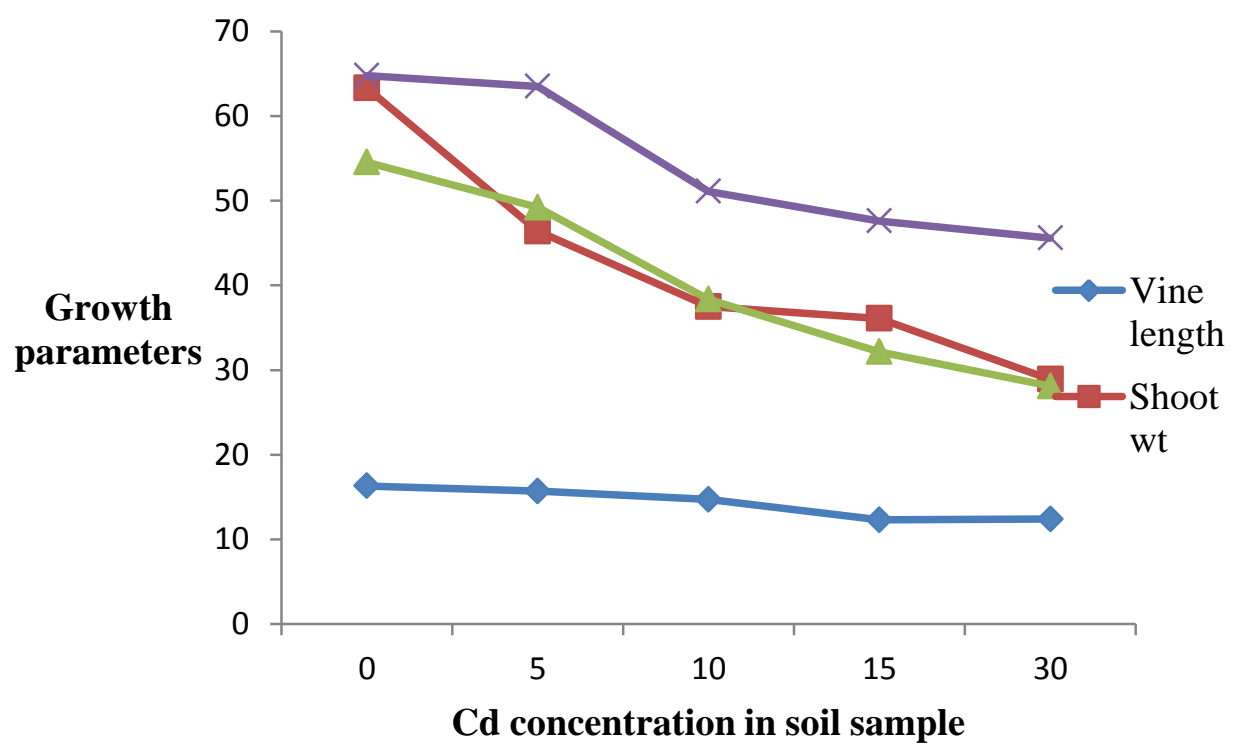

Figure 2: Effect of [Cd] on Growth parameters of 21day old maize seedling

The leaf area were barely unaffected by cadmium contamination as there were no significant differences in the mean values of the control and the test groups for respective periods of 7 and 21 days. This may be due to low rate of assimilation of cadmium from root to other parts of the plant, especially to the leaf. However, the result of this study is not in complete agreement with that claimed by Chugh and Sawhney (1996) and Vassilev \& Yordanov (1997) that under high cadmium concentration, the overall plant growth, seed germination, chlorophyll synthesis and other physiological and metabolic processes are inhibited. From correlation studies, germination percentage showed positive and highly significant correlation with shoot length, fresh shoot weight, and leaf area. However, there was positive but no significant correlation between germination percentage and fresh root weight for the 7day old seedlings (Table 2). Also, Shoot 
length showed highly significant and positive correlation with fresh shoot weight, fresh root weight, and leaf area for both the 7 and 21day old seedlings respectively. These results are in complete agreement with the findings of Muhammad et al. (2007) that shoot length showed highly significant and positive correlation with fresh shoot weight and fresh root weight. The fresh shoot weight exhibited positive and significant correlation with fresh root weight and leaf area. Furthermore, for the 21day old seedling, there was no significant correlation between germination percentage and fresh shoot weight (Table 3).

\section{REFERENCES:}

Ademoroti; C. M. A. (1996). Standard Methods for Water and Effluents Analysis. Mareh Prints and consultancy, BDPA, Ugbowo, Benin City- Nigeria.

Al-Salama, Y.J.(2002): Studies on certain elements forms as pollutants in some soils of Egypt using nuclear techniques. Ph.D thesis, soil science, faculty of agriculture. Ain Shams University, Cairo, Egypt.

Amitaye, A.N. (2011). Physicochemical and Microbiological Assessment of both River and Borehole Water sources from Obiaruku town in Delta state. Unpblished MSc thesis, University of Benin, Benin city, Edo state, Nigeria.

Bahrami, H; Razmjoo, I.; Ostadi, J; Afari, A. (2012): Effect of drought stress on germination and seedling growth of Sesame cultivars (Sesamum indicum I). International Journal of Agric.Science, 2(5):423-428

Belimov, A.A., Hontzeas, N., Safronova, V.I., Demchinskaya, S.V., Piluzza, G., Bullitta, S. \& Glick, B.R. (2005). Cadmiumtolerant plant growth-promoting bacteria associated with the roots of Indian mustard (Brassica juncea L. Czern.). Journal of Soil Biology \& Biochemistry, 37: $241-250$

\section{CONCLUSION:}

The results obtained shows that the biomass production as well as the leaf area was not significantly affected by the cadmium stress on the Zea mays seedlings. Therefore, based on the reported high uptake efficiency of cadmium by Zea mays seedling, Zea mays may be considered an important component of phytoremediation technology for cadmium removal.

Burton, M.A.A \& Peterson, P.J. (1979): Metal accumulation by aquatic bryophyte from polluted mine stream. Journal of Environmental Pollution, 19:23-26.

Chappell, J. (1997). Phytoremediation of TCE using Populus. EPA Technology Innovation Office, Washington D.C..

Cunningham, S. D., Anderson, T. A., Schwab, A. P., \& Hsu, F. C. (1996). Phytoremediation of soils contaminated with organic pollutants. Advances in Agronomy, 56: 55-114.

Chugh, L.K. and Sawhney, S.K. (1996). Effects of cadmium on germination, amylases and rate of respiration of germinating pea plants. Environmental Pollution, 92(1): 15.

Gomez, K.A. and Gomez, A.A. (1984): Statistical procedures for agricultural research. New York: John Wiley.

Greger, M. \& Landberg, T. (1995): Cadmium accumulation in salix in relation to cadmium concentration in the soil. Report from Vattenfall Utveckling $A B$ 1995/9 in Sweden.

Greger, M.(1997): Willow as phytoremediator of heavy metal contaminated soil. Proceedings of $2^{\text {nd }}$ international conference on element cycling in thr environment, Warsaw, 167-172.

Jacob, J.O.; Ajai, A.I.,; Amadi, A.N.(2013): Heavy metal toxicity: a review. Proceedings of 


\section{Nigerian Journal of Basic and Applied Science (June, 2017), 25(1): 111-119}

the $36^{\text {th }}$ Annual International Conference of the Chemical Society, Minna, Nigeria: 268-273

Kumar, P.B.A., Dushenkov, V., Motto, H., Raskin, I., 1995. Phytoextraction: the use of plants to remove heavy metals from soils. Journal of Environmental Science and Technology, 29: 1232-1238.

McCutcheon, S.C. \& Schnoor, J.L. (2003). Phytoremediation. Hoboken NJ: John Wiley and Sons.

Miller, R.W; Alkhazraji, M.L.; Sisson, D.R. (1995): Alfalfa growth and absorption of cadmium from soil amended with sewage sludge. Journal of agricultural science, 52(2): 179-184.

Muhammad, R; Muhammad, M; Mahmood ul, H; Munir, A; and Muhammad, A (2007): Performance of wheat genotypes under osmotic stress at germination and early seedling growth stage. African Journal of Biotechnology, 6(8): 971-975.

Ogboi, E. (2005). Understanding Conservation and Environmental Problems in the tropics.Sunny Integrated Press and Publishing Company, Delta State, Nigeria.

Okuo, J. M. Okonji, E.I. \& Omoyereri, F.R. (2007). Hydrophysico-Chemical Assessment of the Warri Coastal Aquifer, Southern Nigeria. Journal of Chemical Society of Nigeria, 32(2): 53-64.

Riffat, N.M.; Syed, Z.H. and Isfaq, N.(2010): Heavy metal contamination and accumulation in soil and wild plant species from industrial area of Islamabad, Pakistan. Pakistan journal of Botany, 42(1):2413-2423.
Schnoor, J. L. (1997). Phytoremediation Pittsburgh: Groundwater Remediation Technologies Analysis Center.

Sharma, B.K. (2006). Environmental Chemistry. Prakashan Media Ltd, Delhi-India.

Shuaibu, U.O.A (2013): Phytoremediation of trace metals in Shadawanka stream of Bauchi metropolis, Nigeria. Proceedings of the $36^{\text {th }}$ Annual International Conference of the Chemical Society, Minna, Nigeria:173-175.

Tukura, B.W.; Anhwange, B.A.; Mohammed, Y. and Usman, N.L. (2012): Translocation of trace metals in vegetable crops grown on irrigated soil along Mada river, Nasarawa state, Nigeria. International Journal of Modern Analytical and Separation Sciences, 1(1):13-22.

Uche, J.I and Amitaye, A.N. (2013): Assessment of heavy metals in borehole water in Obiaruku town, Delta-state, Nigeria. Proceedings of the $36^{\text {th }}$ Annual International conference of the Chemical Society, Minna, Nigeria: 91-95.

Vassilev, A. and Tordanov, I. (1997). Effects of cadmium on the physiological state and photosynthetic activity of young barley plants. Photosynthetical, 34 (2): 293-302.

Wong, J.W.C.(1996): Heavy metal contents in vegetables and market garden soil in Hong Kong. Journal of Environmental Technology , 17:407-410.

Zhi-xin Niu, Li-na Sun; Tie-heng Sun; Yushuang Li \& Hong Wang (2007): Evaluation of phytoextraction of cadmium and lead by sunflower, ricinus, alfalfa and mustard in hydrophonic culture. Journal of Environmental Science, 19:961-967. 